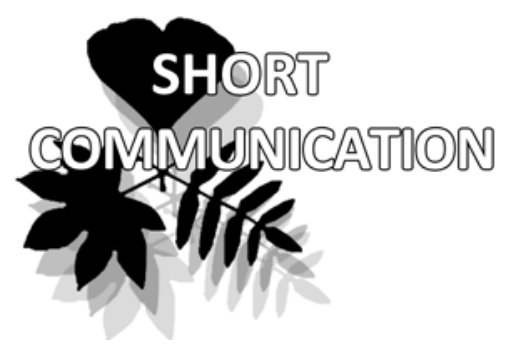

Kirill A. Korznikov

e-mail: korzkir@mail.ru

Botanical Garden-Institute FEB RAS, Vladivostok 690024 Russia

Manuscript received: 17.11 .2015

Review completed: 10.02 .2016

Accepted for publication: 12.02 .2016

Published online: 06.05.2016

\section{Naturalization of Pinus mugo Turra (Pinaceae) in southeast Sakhalin, Russia}

\author{
Kirill A. Korznikov
}

\begin{abstract}
A B S T R A C T
The paper presents information about the discovery of Pinus mugo with trees of various ages on coastal terrace between the Igrivaya and Ostrovka rivers $\left(46^{\circ} 25^{\prime} 25^{\prime \prime} \mathrm{N}, 143^{\circ} 20^{\prime} 10^{\prime \prime E}\right.$; Tonino-Aniva Peninsula, Korsakov District). Unlike other pine species that come from outside the district that have been cultivated at different times on Sakhalin, P. mugo reproduces well naturally. The dispersal of this species may be confined exclusively to the habitats found on the coastal terrace of Aniva Bay on the Sea of Okhotsk.
\end{abstract}

Ke ywords : mountain pine, floristic record, alien species, introduced species, forest plantation, vacant niches

\section{P E 3 Ю M E}

Корзников К.А. Натурахизация Pinus mugo Turra (Pinaceae) на юговостоке Сахалина, Россия. Приводится информация о находке разновозрастной популяции Pinus mugo на морской террасе побережья Анивского залива, межАу реками Игривая и Островка (46² $25^{\prime} 25^{\prime \prime} \mathrm{N}, 143^{\circ} 20^{\prime} 10^{\prime \prime} \mathrm{E}$; Тонино-Анивский полуостров, Корсаковский административный район). В отличие от Аругих инорайоных виАов сосен, культуры которых в разное время создавали на Сахамине, $P$. mияо хорошо возобновляется естественным образом. Аальнейшее расселение этого виАа, возможно, будет приурочено исключительно к биотопам морских террас Анивского залива Охотского моря.

К $\boldsymbol{\Lambda}$ ю ч е в ы е с $\mathbf{\Lambda}$ о в а: сосна горная, флористическая находка, чужеродный виА, интродуцент, Аесные культуры, свободная экологическая ниша
During a botanical field work trip of 25.08.2015, in the Tonino-Aniva Peninsula coastal plain, between the Igrivaya

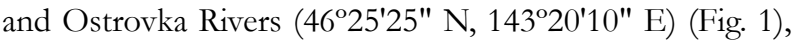
we found a various age population of pine that we identified as Pinus mugo. A comparison of the plant specimens we collected (Fig. 2) with those stored in the Moscow State University Herbarium (MW) confirmed that our identification was correct. The specimens were submitted to MW.

Species P. mugo is not included in the checklist of the vascular plants of Sakhalin (Barkalov \& Taran 2004). Cultivated stands of $P$. mugo were not mentioned in the available Sakhalin forestry, geobotanical or flora documentation. Pinus pumila (Pall.) Regel is the only member of the genus Pinus native to the island.

The habitat of the mountain pine is a gently sloping coastal terrace facing west towards Aniva Bay on the Sea of Okhotsk, cut through and drained by small ravines. P. mugo forms open woodlands with a large number of young plants 3-4 $\mathrm{m}$ in height, $8-10 \mathrm{~cm}$ in diameter and smaller. Growth rings found in the tree cores showed that the trees of this size are up 20 years old. The pine naturalized out cultivated stands planted age of about 30 years, $7.5-8.5 \mathrm{~m}$ in height, $12-14 \mathrm{~cm}$ in diameter. The trees that had reached reproductive age all had produced a massive amount of seeds. We counted about 3000 trees of various ages on 17 hectares in marine terrace (Fig. 3).
Pinus mugo sometimes mixes with Betula ermanii Cham., Picea jezoensis (Siebold \& Zucc.) Carrière, Abies sachalinensis F. Schmidt, Larix cajanderi Mayr Acer mayrii Schwer., Betula ermanii Cham., Salix caprea L. and Pinus sylvestris L. (the latter is naturalized from planting). The maximum height of the trees in surrounding forest stands does not exceed $10 \mathrm{~m}$, and the most typical height is 7-8 m. Most trees have a flag-shaped crown. There are numerous Hydrangea paniculata Siebold shrubs, although this species doesn't form closed canopy. Occasionally there were Vaccinium ovalifolium Sm., Menziesia pentandra Maxim., Juniperus sibirica Burgsd. The dominant of herb layer cover consists of Lycopodiaceae and Ericaceae: Lycopodium clavatum L., Diphasiastrum complanatum (L.) Holub, Lycopodium juniperoideum Sw., Vaccinium vitis-idaea L., $V$. praestans Lamb. Commonly found plants are: Osmundastrum asiaticum (Fernald) Tagawa, Chamaepericlymenum canadense (L.) Asch. \& Graebn., Angelica genuflexa Nutt. ex Torr. \& A. Gray, Bupleurum longiradiatum Turcz., Calamagrostis langsdorffii (Link) Trin., Artemisia spp., and other species. Among the protected species are founded Juniperus sargentii (A.Henry) Takeda ex Koidz., Aralia cordata Thunb. and Neottianthe cucullata (L.) Schlechter. Adjacent to the surveyed area are cultivated stands of Abies sachalinensis.

Apparently, before the clear-cutting of the forest in the early 20th century, the vegetation between the rivers Igrivaya and Ostrovka consisted of dark coniferous forests 

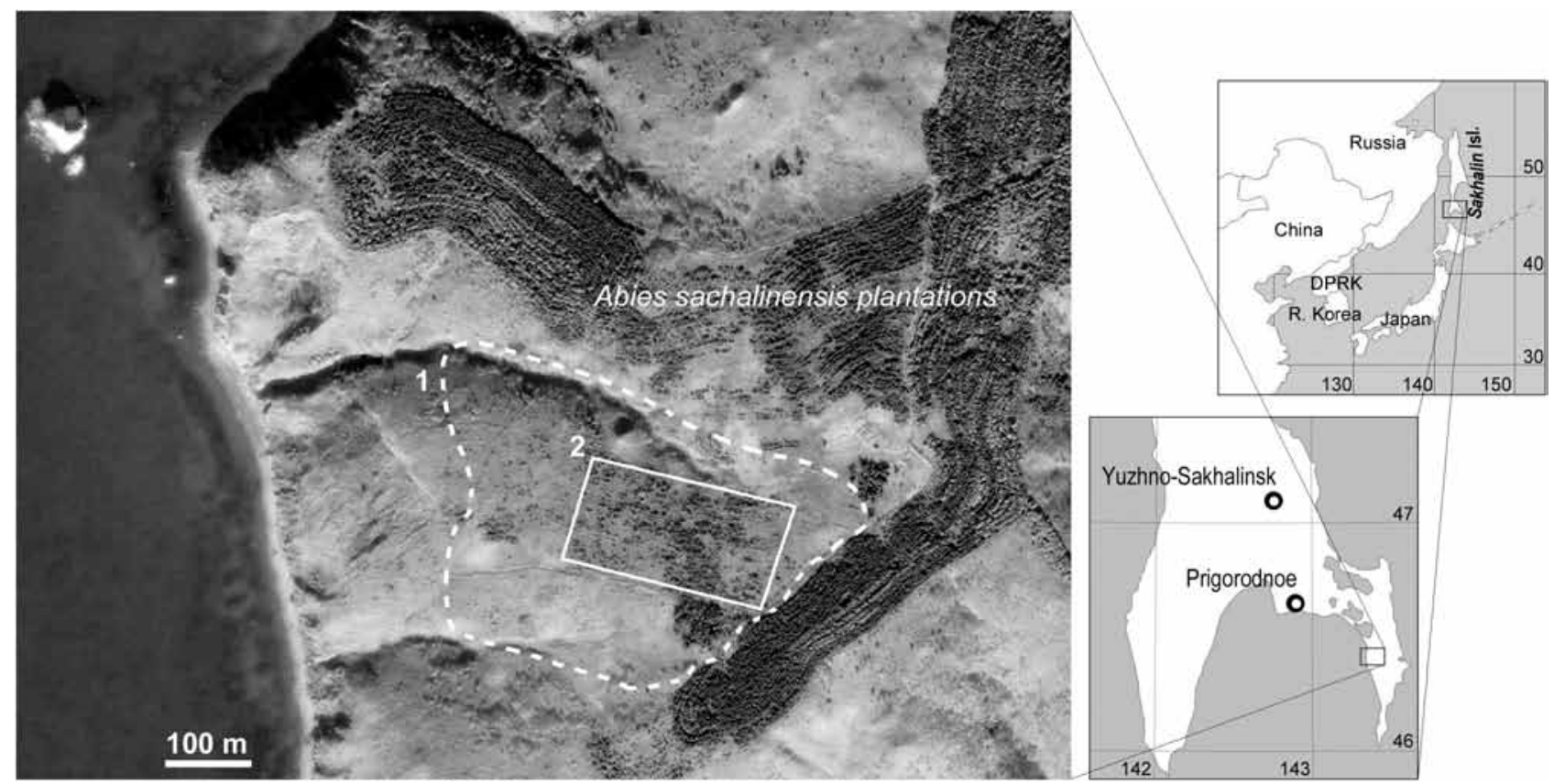

Figure 1 Location of mountain pine population found on Sakhalin Island: 1 - site with natural regeneration of P. mugo (17 ha, dashed line), $2-P$. mugo plantation (4 ha, solid line)

dominated by $A$. sachalinensis, with local areas showing a predominance of Acer mayrii and Quercus crispula in the presence of Betula ermanii. Today, the existing plant communities are longterm derivative stages of regenerative succession, which also contributed to the opening of an ecological niche for the mountain pine.

Also on October 2015, according to data from personal observation by Prof. Eryomin, we found the second place of cultivated stands of 40 years old $P$. mugo in an area of about 0.25 ha near the Prigorodnoe liquefied natural gas plant (463'ㄹ" N 142 51'12"E, Korsakov District).

The natural range of $P$. mugo is limited to the mountainous areas of Central and Southern Europe. It occurs usually in the sub-alpine zone above the timberline (1400-2700 m), but the species can grow at much lower altitudes (as low as $200 \mathrm{~m}$ ) in frost hollows and peat bogs (Christensen 1987). The naturalization of $P$. mugo in European countries outside its natural range is summarized in a report by Jørgensen (2010). P. mugo now grows in Denmark, Norway, Sweden, and the Baltic States. In Russia, P. mugo in cultivated stands can reach Leningrad Province (Maleev 1949). There are unique cases of naturalization in Moscow Province (Syreyshchikov 1927). In North America (specifically in Ontario, Canada) it has been observed entering into natural plant communities in dry, rocky, and sandy habitats (Catling 2005). The introduction of P. mugo into natural communities may lead to a decrease in plant species diversity (Catling
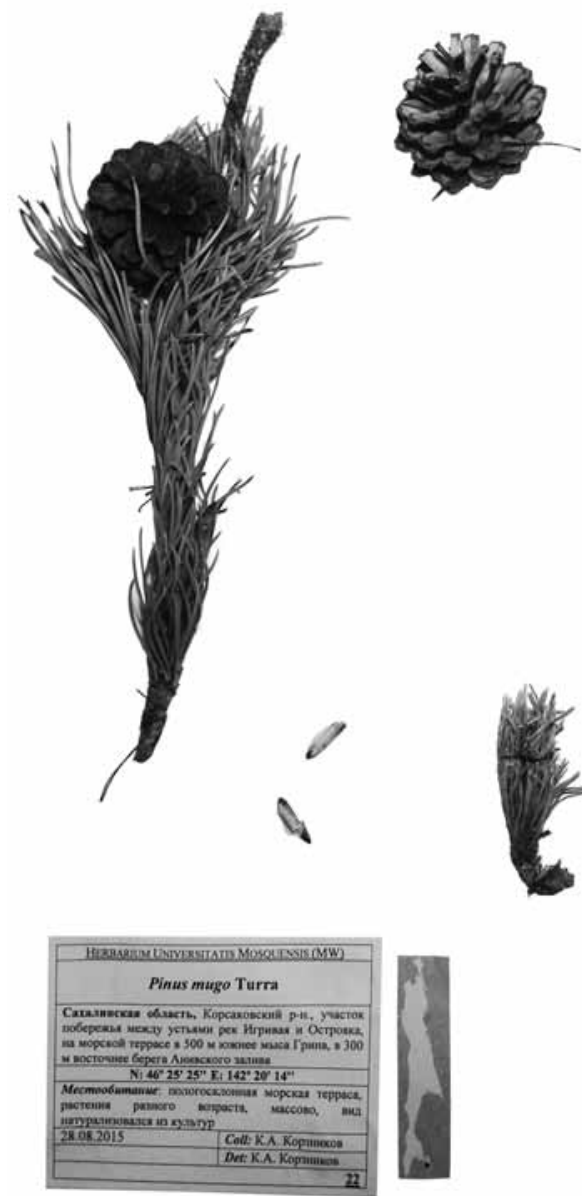

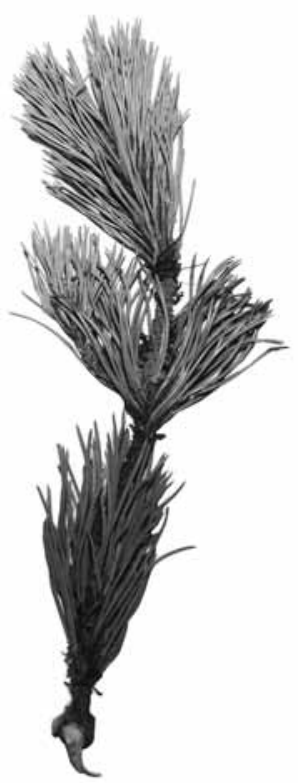

Figure 2 Herbarium specimen of Pinus mugo in MW 

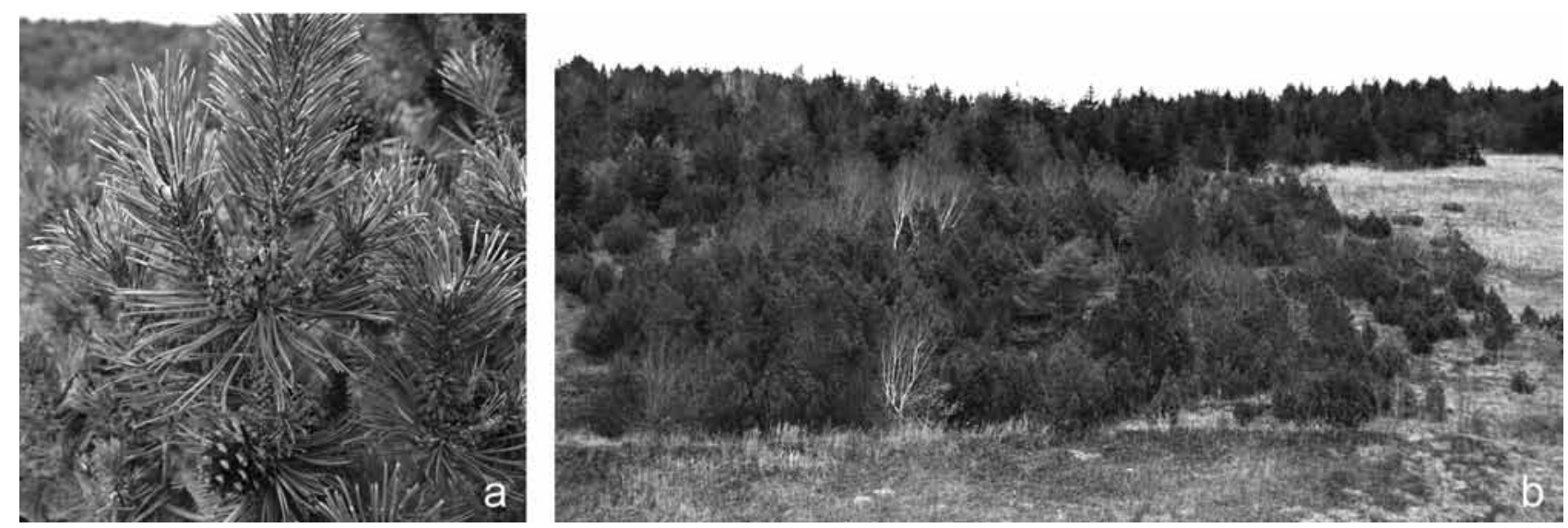

Figure 3 Pinus mugo from study site: a - 20-year-old treelet with reproductive organs; b - one of the P. mugo clusters, October 2015

2005, Zeidler et al. 2012) and the restructuring of the functional relationships in ecosystems (Kašák et al. 2015).

USSR forestry workers experimented with the introduction of P. mugo in southern Sakhalin in 1970-1980s. It should be noted that Japanese botanists created plantations of East Asian representatives of the Pinaceae from outside Sakhalin on the island in the first half of the 20th century with both very successful (Larix kaempferi (Lamb.) Carrière) and not very successful ( $P$. densiflora Siebold \& Zucc., P. thunbergii Parl.) results. That said, there are stands of trees, P. densiflora, P. thunbergii, and Chamecyparis pisifera (Siebold \& Zucc.) Endl. planted over 80 years ago in southern Sakhalin towns that are presently in good condition. Cryptomeria japonica was cultivated by Japanese foresters, and the trees were quite successful in the vicinity of Shebunino, a village in the far southwest of Sakhalin (Voroshilova 1978), but were cut down. In post WWII times, foresters started creating forest plantations of P. sylvestris L. and P. koraensis Siebold \& Zucc. (Vlasova et al. 2010), although attempts at their introduction were made before 1945 (Smirnov 2013). In southeast and central Sakhalin there are known plantings of P. banksiana Lamb. (Barkalov \& Taran 2004). This species is used in a limited way in Yuzhno-Sakhalinsk landscaping.

While it has been said that the natural population regeneration of any pine species originating outside Sakhalin is weak or non-existent, and they have no prospects for natural reproduction (Smirnov 2013), this is not the case for the mountain pine. The discovery of a self-sustaining $P$. mugo population with trees of various ages indicates the possibility of the successful existence of this species, at least in the habitats found on the coastal terrace of southeast Sakhalin.

The mountain pine can be used in landscaping cities in the south of Sakhalin, and it is an alternative to $P$. pumila in green building. The possibility for $P$. mugo to be used to stabilize sandy slopes in erosion control measures and for the restoration of sand pits (etc.) requires more detailed research.

\section{ACKNOWLEDGEMENTS}

The author thanks R.M. Shatrov (Sakhalin Environment Watch) for the organization of our field work trips, and V.M. Eryomin (Institute of Marine Geology and Geo- physics, Sakhalin State University) and S.V. Dudov (Moscow State University) for their advices and assistance in the preparation of this article.

\section{LITERATURE CITED}

Barkalov, V.Yu. \& A.A. Taran 2004. A Checklist of vascular plant species of Sakhalin Island. In: Rastitelnyi $i$ zhivotnyi mir ostrova Sakhalin (Materialy Mezhdunarodnogo sakhalinskogo proekta), Chast' 1, pp. 39-66, Dal'nauka, Vladivostok (In Russian with English summary). [Баркалов В.Ю., Таран А.А. 2004. Список видов сосудистых растений острова Сахалин // Растительный и животный мир острова Сахалин (Материалы Международного сахаминского проекта). Часть 1. ВАадивосток: Аальнаука, 2004. C. 39-66].

Catling, P.M. 2005. Identification and status of the introduced black pine, Pinus nigra, and mugo pine, Pinus mugo, in Ontario. Canadian Field-Naturalist 119(2):224-232.

Christensen, K.I. 1987. Taxonomic revision of the Pinus mugo complex and $P . \times$ rbaetica $(P$. mugo $\times$ sylvestris) (Pinaceae). Nordic Journal of Botany 7(4):383-408.

Jørgensen, H. 2010. NOBANIS Invasive Alien Species Fact Sheet - Pinus mugo. In: Online Database of the European Network on Invasive Alien Species - NOBANIS <www.nobanis. org >. Last accessed: 19.09.2015.

Kašák, J., M. Mazalová, J. Šipoš \& T. Kuras 2015. Dwarf pine: invasive plant threatens biodiversity of alpine beetles. Biodiversity and Conservation 24(10):2399-2415.

Maleev, V.P. 1949. Pinus L. - pine. In: Derev'ia $i$ kustarniki SSSR, vol. 1, (S.Ya. Sokolov, B.K. Shishkin, eds), pp. 184 266, Izdatel'stvo Akademii nauk SSSR, Moscow, Leningrad (in Russian). [Малеев В.П. 1949. Рinus L. - сосна // Аеревья и кустарники СССР. Т.1. / поА реА. С.Я. Соколова, Б.К. Шишкина. М.-.$:$ ИзА-во Академии наук CCCP. C. 184-266].

Syreyshchikov, D.P. 1927. Identification guide of plants of Moscow Province. Izdatel'stvo obshchestva izucheniya Moskovskoy gubernii, Moscow, 294 pp. (in Russian). [Сырейщиков А.П. 1927. Определитель растений Московской губернии. М.: ИзА-во общества изучения Московской губернии. 294 с.].

Smirnov, A.A. 2013. Introduction and naturalization of coniferous trees on Sakhalin Island. Lesnoi zhurnal 5(335): 213-217 (in Russian with English abstract). [Смирнов А.А. 2013. Интродукция и натурахизация хвойных на Сахалине // Аесной журнац. № 5 (335). C. 213-217.] 
Vlasova, I.I., V.M. Eryomin \& A.V. Kopanina 2010. Plantings of scotch pine on Sakhalin. Izvestiia Samarskogo nauchnogo tsentra RAN 12 (1-3): 863-866 (in Russian with English abstract). [ВАасова И.И., Ерёмин В.М., Копанина А.В. 2010. Культуры сосны обыкновенной на Сахалине // Известия Самарского научного центра РАН. Т. 12, № 1-3. C. 863-866].

Voroshilova, G.I. 1978. Cryptomeria japonica on Sakhalin Island. Biulleten' Glavnogo botanicheskogo sada 109:23 (in Rus- sian). [Ворошимова Г.И. 1978. Криптомерия японская на Сахамине // Бюмлетень ГАавного ботанического сада. № 109. С. 23].

Zeidler, M., M. Duchoslav, M. Banaš \& M.Lešková 2012. Impacts of introduced dwarf pine (Pinus mugo) on the diversity and composition of alpine vegetation. Community Ecology 13(2): 213-220. 